\title{
Ondernemen in Nederlands-Indië c.1900-1940
}

\section{J. TH. LINDBLAD}

Gamboeng had een heel bijzondere sfeer, zeer conservatief. De onderneming lag vrij eenzaam en de bevolking had zich weinig vermengd met vreemde elementen. De oude gebruiken bleven er dan ook nog steeds gelden en de verhouding tussen landheer en opgezetenen had iets aartsvaderlijks behouden. 's-Middags aan de thee, in de ruime voorgalerij, kwamen twee mandoers [ = opzichters] verslag uitbrengen. $\mathrm{Zij}$ zaten dan met gekruiste benen boven aan de trap en wachtten tot zij werden aangesproken om dan op plechtige toon en met de nodige sembahs [= betuiging van eerbied] te antwoorden. Maar ondanks dit 'afstand bewaren' was er een hechte band tussen de gedoeng [= het landhuis] en de bevolking 1 .

Dit zijn de lyrische bewoordingen waarin Hella Haasse in haar Heren van de thee, dat vorig voorjaar uitkwam, het ondernemersklimaat in het toenmalige Nederlands-Indië beschrijft. De beschrijving van de thee- en kina-ondememing Gamboeng in de Preanger in West-Java dateert uit 1902. Dertig jaar daarvoor was ze opgezet door de zojuist uit Nederland gekomen, jonge ingenieur Rudolf Kerkhoven uit Overijssel. De onderneming was zijn levenswerk en in totaal zou hij daar 45 jaar lang de scepter zwaaien.

Dezelfde onderneming treffen we, in minder lyrische bewoordingen, aan in het Handboek voor cultuur-en handelsondernemingen in Nederlands-Indië, een jaarlijkse uitgave van De Bussy in Amsterdam waarin alle bedrijven werkzaam in de kolonie vermeld staan. Daar lezen we dat de cultuur-maatschappij Gamboeng als NV was opgericht in 1921. De zetel bevond zich in Bandoeng terwijl de landbouwonderneming zelf in het dorp Bandjaran lag. Het maatschappelijk kapitaal van de NV bedroeg $f 480.000,-$. Alle aandelen waren volgestort en in de jaren twintig werd er geen dividend uitgekeerd ${ }^{2}$.

De cultuur-maatschappij Gamboeng kan beschouwd worden als prototype van een door Nederlandse ondernemers beheerd bedrijf in Nederlands-Indië gedurende de laat-koloniale periode. Het bedrijf was kleinschalig en gericht op de produktie van grondstoffen voor de wereldmarkt. Het lag geïsoleerd en bracht een symbiose tot stand tussen geïmporteerd Nederlands ondernemerschap en plaatselijke inheemse arbeid. De arbeidsverhoudingen waren hiërarchisch en werden graag van Nederlandse zijde als welwillend-patriarchaal beschouwd - of de inheemsen dat óók zo zagen is een ander verhaal.

Ondernemen in Nederlands-Indië moeten wij bezien tegen de achtergrond van de mogelijkheden om rendabel in de kolonie te investeren. Voor het particuliere kapitaal

1 H. Haasse, Heren van de thee (Amsterdam, 1992) 258.

2 Handboek voor cultuur-en handelsondernemingen in Nederlandsch-Indië 1930 (Amsterdam, 1931 ). 
deden dergelijke mogelijkheden zich voor na 1870; in het daaropvolgende laatkoloniale tijdperk hadden grootschalige investeringen van buitenlands kapitaal in Nederlands-Indië plaats. De komst van particulier kapitaal in de kolonie viel samenen dat was geenszins toevallig - met de uitbreiding en daadwerkelijke vestiging van het Nederlandse gezag in alle uithoeken van de archipel $^{3}$.

De geleidelijke opbouw van Westerse investeringen in de kolonie betekende een verbreding en vervlechting van particuliere ondernemingen in ruimtelijke zin en hield tevens een waarborg in voor de continuïteit op de langere termijn. Aldus ontstond in Nederlands-Indië een fijnmazig netwerk van op Westerse leest geschoeide bedrijven. De expansie van de Westerse investeringen liep door tot aan de vooravond van de depressie in de jaren dertig. Wanneer wij dit netwerk nader bezien, bij voorkeur op zijn hoogtepunt omstreeks 1930, dan beseffen wij dat elke afzonderlijke onderneming slechts een schakel in een groter, samenhangend geheel vormde.

Ondernemen in de kolonie was anders dan thuis. Het bijzondere karakter van de bedrijfsvoering in Nederlands-Indië vloeide voor een deel voort uit de grote fysieke afstand tot het moederland en de veelvuldig voorkomende noodzaak om ter plekke pionierswerk te verrichten bij het openleggen van maagdelijke gebieden, in het bijzonder op de eilanden buiten Java. Van belang waren tevens de keuze van de technologie bij het combineren van de produktiefactoren en het tijdsperspectief waarin de uiteindelijke baten beoordeeld moesten worden.

In dit artikel zullen achtereenvolgens aan de orde komen het ontstaan van particuliere Westerse ondernemingen in Nederlands-Indië, het aldus ontstane netwerk van ondernemingen en tenslotte het bijzondere karakter van de bedrijfsvoering.

\section{Ontstaan van het Westerse bedrijfsleven}

$\mathrm{Na}$ de afschaffing van het cultuurstelsel in 1870 werd Nederlands-Indië opengesteld voor particulier, in het bijzonder Nederlands, kapitaal. Het heeft echter enkele decennia geduurd voordat de particuliere investeringen goed op gang kwamen. Dat kunnen we het best afleiden uit de schaarse, globale schattingen van de gecumuleerde investeringen van Westers kapitaal in de kolonie: 750 miljoen gulden in 1900, 1,5 miljard in 1914 en 4 miljard in 1930; daarna was er ten gevolge van de depressie een terugval tot ca. 3,5 miljard in 1940. Tweederde van dit totaal was kapitaal van Nederlandse oorsprong ${ }^{4}$.

Twee vragen dringen zich in dit verband op. Ten eerste, waarom heeft het zo lang geduurd voordat de binnenkomende kapitaalstroom aanzienlijke vormen aannam? Ten tweede, wat ging er schuil achter de versnelling van dit proces tussen 1914 en 1930 ? Voor een belangrijk deel moet het antwoord op beide vragen gezocht worden

3 Zie verder: J. van Goor, ed., Imperialisme in de marge. De afronding van Nederlands-Indië (Utrecht, 1986).

4 J. Th. Lindblad, 'Foreign investment in late-colonial and post-colonial Indonesia', Economic and social history in the Netherlands, III (1991) 183-208, i.h.b. 189. Het beste overzicht uit de tijd zelf is te vinden in: H. G. Callis, Foreign investment in Southeast Asia (New York, 1941) 28-41. 
in de relatie tussen enerzijds de particuliere kapitaalinvesteringen in de kolonie en anderzijds de expansie van de uitvoer van Nederlands-Indië. Tot de eeuwwisseling verliep deze expansie betrekkelijk traag maar aan de vooravond van de eerste wereldoorlog en in de jaren twintig trad een markante versnelling op. In zekere zin hebben we hier te maken met een kip-en-ei kwestie. De expansie van de export verliep traag omdat er te weinig geïnvesteerd werd in de produktiecapaciteit terwijl de investeringen bescheiden bleven omdat de afzetmogelijkheden op de wereldmarkt nog niet florissant genoeg waren. We mogen aannemen dat investeringen en uitvoer elkaar op dezelfde wijze versterkten toen de expansie eenmaal was begonnen.

Het is instructief de relatie tussen investeringen en uitvoer iets systematischer uit te werken. Dit doen we zowel grafisch als door middel van een eenvoudige regressieanalyse. Het meten van de omvang der investeringen op jaarbasis levert een bronnentechnisch probleem op. Globale schattingen lenen zich hier niet voor omdat deze slechts betrekking hebben op momentopnames. We zijn aangewezen op schattingen die naderhand gemaakt zijn door Creutzberg op grond van schadeclaims ingediend door bedrijven die in 1957-1958 door de Indonesische regering werden genationaliseerd. Creutzbergs reeks is per definitie onvolledig omdat niet alle bedrijven uit het Interbellum nog in 1957 werkzaam waren. Bovendien is deze reeks, wederom per definitie, beperkt tot ondernemingen met Nederlandse eigenaren. Desalniettemin bestaat de indruk dat Creutzbergs reeks de algemene tendens in grote lijnen weerspiegelt.

\section{GRAFIEK I}

Investeringen en uitvoer 1910-1940

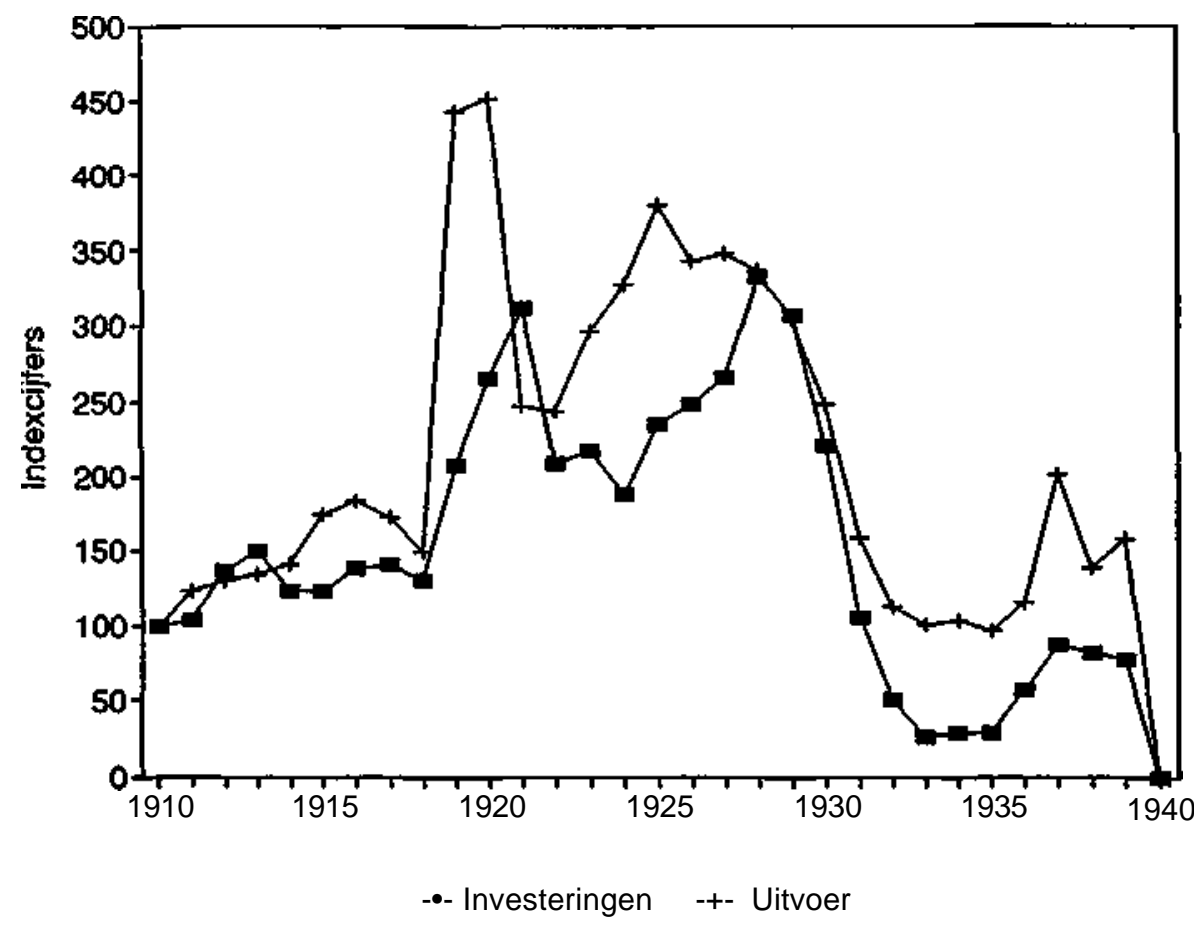


In de grafische weergave van de jaren 1910-1939 komt het parallelle verloop van investeringen en uitvoer naar het buitenland duidelijk naar voren (grafiek I) ${ }^{5}$. Ook de regressie-analyse wijst op een niet te verwaarlozen verband; de correlatie-coëfficiënt is $0,81\left(\mathrm{R}^{2}=0,66\right)$.

We kunnen derhalve de aanvankelijk vertraagde en later versnelde instroom van buitenlands, vooral Nederlands kapitaal in de kolonie met name relateren aan de ontplooiing van Nederlands-Indië als een belangrijk deelnemer aan de wereldhandel; de afzetmogelijkheden van primaire produkten en grondstoffen op de wereldmarkt gaven daarbij de doorslag. Overigens kwam dit verkeer niet noodzakelijkerwijs de bilaterale handel tussen moederland en kolonie ten goede. Sterker nog, de toenemende financiële verstrengeling van Nederland met zijn kolonie in de laat-koloniale periode ging gepaard met een zekere commerciële emancipatie van Nederlands-Indië ${ }^{6}$.

Het is belangrijk om tevens oog te hebben voor een creatie van de laat-koloniale periode, het gelijktijdige proces van koloniale staatsvorming, waarin economische en politiek-bestuurlijke factoren met elkaar vermengd waren. Zo moeten we het uitblijven van grootschalige investeringen vóór 1890 of 1900 zien in het licht van de nog zeer onvolledige bestuurlijke greep van het gouvernement op het leven in met name de Buitengewesten. Soms werd dit heel evident zoals wanneer de goedkeuring van concessies in afgelegen streken jarenlang door Batavia werd opgehouden omdat het bestuursapparaat ter plaatse er nog niet rijp voor was. Zo duurde het bijvoorbeeld van 1882 tot 1888 voordat de concessie verleend door de sultan van Koetei in Oost-Borneo ingebracht kon worden in een NV, de Steenkolen-Maatschappij Oost-Borneo ${ }^{7}$.

Het ontstaan van de koloniale staat kan het best worden beschreven als het ontstaan van een complex netwerk van bestuurlijke knooppunten. A Campo laat in zijn dissertatie over de KPM (Koninklijke Paketvaart Maatschappij) zien hoe de bestuurlijke, maritieme en economische netwerken deels samenvielen en elkaar vaak versterkten $^{8}$. Bij de groei van een netwerk speelt het cumulatieve aspect een cruciale rol: nieuwe economische of bestuurlijke vestigingen ontstaan gemakkelijker zodra het gebied in kwestie opgenomen is in het maritieme netwerk. Dit deed zich ook voor bij de ontwikkeling van het Westerse bedrijfsleven in de kolonie.

Van de ontstaansgeschiedenis komen we welhaast vanzelf bij het uiteindelijke resultaat, het conglomeraat van Westerse ondernemingen dat de economische structuur van Nederlands-Indië in het laat-koloniale tijdperk is gaan bepalen.

5 Bronnen voor Grafiek I: P. Creutzberg, Changing economy in Indonesia, III, Expenditure on fixed assets ('s-Gravenhage, 1977) 44-46; W. L. Korthals Altes, Changing economy in Indonesia, VII, Balance of payments 1822-1939 (Amsterdam, 1987) 109-110.

6 J. Th. Lindblad, 'De handel tussen Nederland en Nederlands-Indië, 1874-1939', Economisch- en sociaal-historisch jaarboek, LI (1988) 240-288, i.h.b. 253-261.

7 J. Th. Lindblad, 'Strak beleid en batig slot. De Oost-Borneo Maatschappij 1888-1940', Economischen sociaal-historisch jaarboek, XXXXVIII (1985) 182-211, i.h.b. 185.

8 J. N. F. M à Campo, Koninklijke Paketvaart Maatschappij. Stoomvaart en staatsvorming in de Indonesische archipel 1888-1914 (Hilversum, 1992) 535-616. 


\section{Het netwerk in de koloniale economie}

Wanneer wij het bedrijfsleven in de kolonie bekijken is het verleidelijk onze aandacht voornamelijk te richten op grote, bekende concerns zoals de BPM (Bataafsche Petroleum Maatschappij) en de Deli-Maatschappij. Deze reuzen waren toonaangevend in respectievelijk de grondstoffenwinning en plantage-economie. Een juister beeld van de werkelijkheid wordt verkregen wanneer we het Westerse bedrijfsleven in de kolonie bezien als een uitgebreid netwerk bestaande uit talloze vestigingen van uiteenlopende grootte en met een andere functie. Deze opvatting wordt hier geïllustreerd aan de hand van een momentopname van het bedrijfsleven uit c. 1930, zoals beschreven in het Handboek voor cultuur- en handelsondernemingen ${ }^{9}$, het eindpunt van een lange periode van economische expansie in Nederlands-Indië ${ }^{10}$.

Rond 1930 omvatte het georganiseerde bedrijfsleven uit het Westen 2.850 afzonderlijke ondernemingen, verspreid over de gehele archipel en alle denkbare bedrijfstakken. De grote variëteit is een belangrijk kenmerk van dit netwerk. Het bedrijfsleven in de kolonie was beslist geen dependance van het bedrijfsleven uit het moederland maar veeleer een volwaardig en compleet netwerk van ondernemingen die elkaar aanvulden en beconcurreerden.

Hoewel het een momentopname betreft, is het toch mogelijk iets te zeggen over de chronologische opbouw van het netwerk; het jaar van oprichting is namelijk steeds in de bron gegeven. Onze verdeling naar decade van oprichting laat een proliferatie van nieuwe vestigingen zien in de jaren tussen 1910 en 1930; dit was blijkbaar de ware

\section{GRAFIEK II}

Verdeling van bedriiven naar oprichting

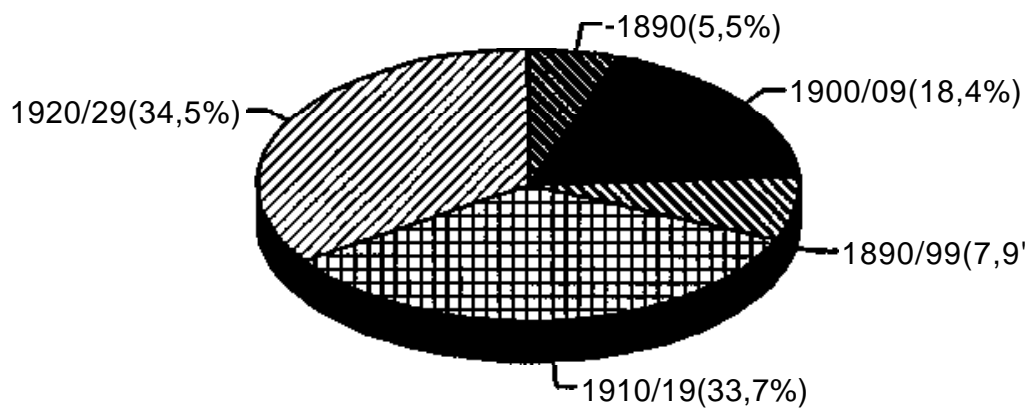

9 Voor een nadere beschrijving van deze bron, zie: J. Th. Lindblad, 'Het bedrijfsleven in NederlandsIndië in het Interbellum', Economisch- en sociaal-historisch jaarboek, LIV (1991) 183-211, i.h.b. 184190. Zie tevens: J. Th. Lindblad, 'Bedrijfsgeschiedenis betreffende Nederlands-Indië (1602-1958)', Jaarboek voor de geschiedenis van bedrijf en techniek, VII ( 1990) 127-142, i.h.b. 140-141.

10 Strict genomen heeft de informatie in de uitgave 1930 van het Handboek betrekking op 1929 (of zelfs 1928 voor wat betreft uitgekeerde dividenden en produktiecijfers). 
Gründerzeit van het bedrijfsleven in de kolonie (grafiek II) 11. Het 'beste' jaar, als het ware, was 1920 toen 170 nieuwe bedrijven werden opgericht. Dit weerspiegelt het optimisme en de euforie van de naoorlogse boom. In de jaren dertig zou overigens een behoorlijk aantal van deze bedrijven weer sluiten.

Ook in geografisch opzicht breidde het netwerk zich voortdurend uit (grafiek III) ${ }^{12}$.

\section{GRAFIEK III}

Verdeling van bedrijven naar regio 1930

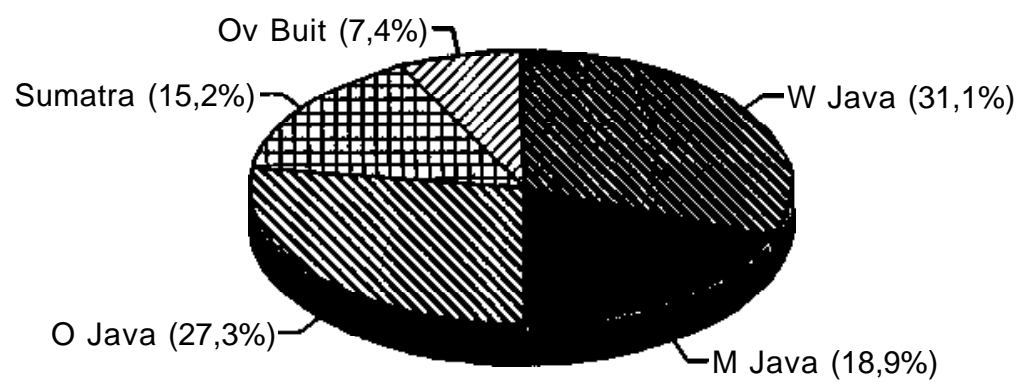

Bijna $60 \%$ van alle ondernemingen was werkzaam op West- of Oost-Java, terwijl minder dan een kwart van het totaal buiten Java werd gevonden. De vijf regio's, waar de belangrijkste activiteiten plaatsvonden, waren de Preanger (387), Batavia (364), Soerabaja (325), Sumatra's Oostkust (217) en Semarang (184). Eveneens populair, maar op een tweede plaats, kwamen residenties zoals Djember in de Oosthoek, Malang, Sumatra's Westkust, Djokjakarta en Soerakarta.

Ondernemen in de kolonie betekende geenszins dat een bedrijf op Java of de Buitengewesten vanuit Nederland werd bestuurd. Opvallend is dat het grootste deel van de Westerse bedrijven in Nederlands-Indië in de kolonie zelf zetelde; deze ondernemingen zijn derhalve eerder als 'Nederlands-Indisch' dan als 'Nederlands' te duiden (grafiek IV) ${ }^{13}$. Interessant is eveneens het grote aantal Chinese ondernemingen, bijna één op vier. Het aantal zuiver Indonesische bedrijven is in de laat-koloniale periode geheel te verwaarlozen (42 in 1930). Het nadrukkelijk Nederlands-Indische

11 Bron voor Grafiek II: Handboek 1930. Vgl. Lindblad, 'Het bedrijfsleven', 190-192. In de bron wordt geen rekening gehouden met de mogelijkheid dat een $\mathrm{NV}$ ontstaan is uit een ter ziele gegane onderneming onder een andere naam.

12 Bron voor Grafiek III: Handboek 1930. De grafiek is gebaseerd op de lokatie van de hoofdvestiging van elk afzonderlijk bedrijf, bij elkaar 2787 ondernemingen; uitgezonderd zijn alleen 16 grote bedrijven die haast overal werkzaam waren en 94 bedrijven waarvan de lokatie niet exact te bepalen viel.

13 Bron voor Grafiek IV: Handboek 1930. Sommige van deze NV's met zetel in Nederlands-Indië zullen ongetwijfeld eigendom zijn van NV's of particulieren in Nederland maar dit kan alleen van geval tot geval worden vastgesteld. 
GRAFIEK IV

Bedrijven naar nationaliteit 1930

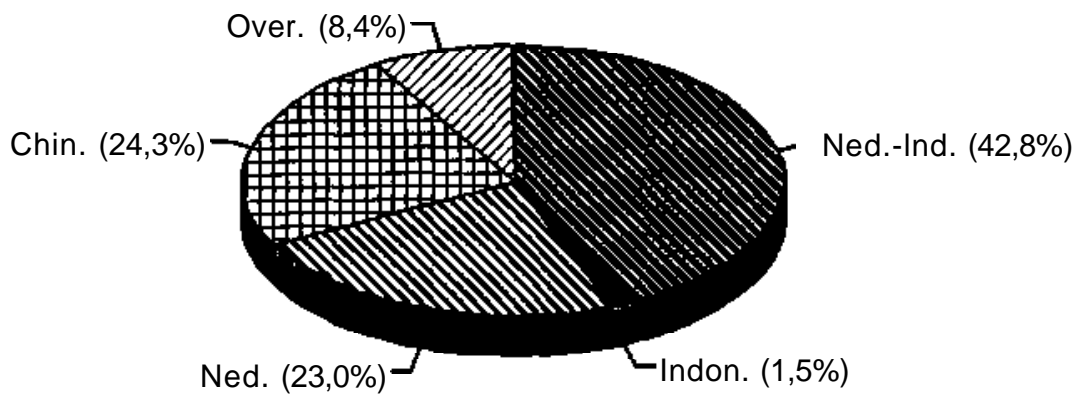

karakter van het bedrijfsleven in de kolonie getuigt van het aanzienlijke economische belang van de permanent in de kolonie woonachtige Nederlandse bevolkingsgroep, het 'Indië' dat apart stond van het moederland maar nooit inheems kon worden in de kolonie $^{14}$.

De vijf voornaamste vestigingsplaatsen van NV's werkzaam in Nederlands-lndië waren: Batavia (380), Amsterdam (363), Soerabaja (334), 's-Gravenhage (194) en Semarang (179). Deze lijst onderstreept de commerciële en administratieve centrumfunctie van de drie grote havensteden op Java. Nog aan het begin van de twintigste eeuw moest Batavia het in economisch opzicht afleggen tegen Soerabaja. De westwaartse verschuiving van het commerciële zwaartepunt op Java vond pas plaats in de jaren twintig en dertig ${ }^{15}$. De grote hoeveelheid ondernemingen met als hoofdkantoor Amsterdam of 's-Gravenhage is niet verbazingwekkend gezien de specialisatiepatronen binnen het Nederlandse bedrijfsleven.

Het netwerk van bijna 3.000 NV's vormde het kader waarbinnen het Westerse bedrijf in de kolonie opereerde. Elke onderneming maakte deel uit van het grotere geheel maar pas op het niveau van het afzonderlijke bedrijf werd beleid gemaakt. Daar werd men geconfronteerd met de bijzondere kenmerken van ondernemen in de kolonie.

\section{Bedrijfsvoering in de verte}

Aan zijn dissertatie over de opkomst en ondergang van het bedrijf 'Insulinde' gaf Kamerling een ondertitel mee die treffend het bijzondere van ondernemen in de

14 Vgl. J. A. A. van Doorn, W. J. Hendrix, Het Nederlands-Indonesisch conflict. Ontsporing van geweld (Amsterdam-Dieren, 1985) 56-59.

15 J. Th. Lindblad, 'Regional patterns in the foreign trade of Java 1911-1940' in: A. H. P. Clemens, J. Th. Lindblad, L. J. Touwen, Changing economy in Indonesia, XII B, Regional patterns in foreign trade 19111940 (Amsterdam, 1992) 19-32, i.h.b. 22. 
kolonie aangeeft: 'Bedrijfsvoering in het onbekende'. Het ging Kamerling er om de interne oorzaken van de opzienbarende instorting van dit bedrijf te benadrukken, eens de grootste industriële onderneming in Nederlands-Indië ${ }^{16}$. Belangrijk daarbij waren de communicatieproblemen, niet alleen vanwege de immense afstand $(12.000 \mathrm{~km})$ maar ook vanwege de onbekendheid van het Nederlandse management met de plaatselijke omstandigheden in Nederlands-Indië. De fysieke obstakels traden in het bijzonder aan het licht ten tijde van de onbeperkte duikbotenoorlog aan het einde van de eerste wereldoorlog toen de telegrafische verbindingen met Nederland lange tijd geheel verbroken waren.

Een klacht die we vaak tegenkomen in de archieven van ondernemingen werkzaam in Nederlands-Indië betreft de kloof tussen de eigenaren of directeuren in Nederland en de beheerders of administrateurs in de Preanger of op de eilanden buiten Java. In het geval van de eerder genoemde Oost-Borneo Maatschappij verzuchtte de directeur na een bezoek aan de kolenmijn in Koetei in 1929: 'te Samarinda wordt dikwerf te weinig vooruitgezien'17. Het leven van Rudolf Kerkhoven op Gamboeng werd mettertijd verzuurd door het onbegrip dat hij meende te bemerken bij mede-aandeelhouders in Nederland ${ }^{18}$. In Nederland wist men wat goed was voor de onderneming in Nederlands-Indië maar ter plaatse wist men het nog beter.

Door de kloof tussen hoofdkantoor en plaatselijke vestiging kreeg de onderneming vaak, als het ware, twee gezichten die weinig of helemaal niet met elkaar harmonieerden. Een goed voorbeeld is de Oost-Borneo Maatschappij. De betekenis van deze onderneming was in Nederland heel anders dan in Koetei aan de oostkust van Borneo. Voor de eigenaren en directeuren in Amsterdam zorgde de afwisseling tussen opbrengsten van cijns voor olieterreinen en de verkoop van steenkolen gedurende de eerste vier decennia van de twintigste eeuw voor een opvallende continuïteit. Ter plaatse was het bedrijf echter vooral een steenkolenmijn die na een slechte start lang op een laag pitje doorsudderde en pas tot bloei kwam in de jaren twintig; in Koetei zelf was discontinuïteit derhalve eerder regel dan uitzondering ${ }^{19}$.

Bij de goud- en zilvermijn 'Salida' aan de westkust van Sumatra was de situatie precies omgekeerd. De ontginning van de mijn vertoont van 1914 tot 1926 een opvallende continuïteit met een betrekkelijk stabiel produktieniveau en stabiele werkgelegenheid. De directeuren en belanghebbenden te ' s-Gravenhage waren echter voortdurend in een machtsstrijd verwikkeld, die uitdraaide op een juridisch conflict tussen de NV's 'Salida' en 'Kinandam' en uiteindelijk bijdroeg tot sluiting van de mijn. Hier treffen we de discontinuïteit in Nederland aan en niet in de kolonie ${ }^{20}$. Zowel 'Salida' als de Oost-Bomeo Maatschappij laten zien dat de kloof tussen Nederland en

16 R. N. J. Kamerling, De N.V. Oliefabrieken 'Insulinde' in Nederlands-Indië. Bedrijfsvoering in de verte (Franeker, 1982) 149-151, 165-169, 239.

17 Lindblad, 'Strak beleid', 196.

18 Haasse, Heren van de thee, 237-250.

19 Lindblad, ' Strak beleid', 188-197.

20 P. T. Schölte, 'De Mijnbouw-Maatschappij 'Salida' in West-Sumatra, 1910-1933' in: A. H. P. Clemens, J. Th. Lindblad, ed., Het belang van de Buitengewesten. Economische expansie en koloniale staatsvorming in de Buitengewesten van Nederlands-Indië 1870-1942 (Amsterdam, 1989) 151-170. 
Nederlands-Indië wortelde in tegengestelde belangen: financiële belangen in het moederland en het belang van produktie voor de export in Nederlands-Indië.

Een ander bijzonder aspect van de bedrijfsvoering in de kolonie was het pionierswerk dat vaak verricht moest worden, in het bijzonder in afgelegen gebieden buiten Java. Hella Haasse geeft een indringende beschrijving van hoe Rudolf Kerkhoven in 1873 zijn thee-onderneming Gamboeng volledig uit het niets opbouwde; toen leek het bedrijf zich ver van de bewoonde wereld te bevinden, maar vandaag ligt het bijna in de buitenwijken van Bandung ${ }^{21}$. Het pioniersbestaan was onlosmakelijk verbonden met ondernemen in de kolonie en sprak in niet geringe mate tot de verbeelding van diegenen die thuis bleven of weg wilden.

Maar we mogen het beeld van de eenzame, stug doorwerkende jonge Hollander in het oerwoud niet al te veel romantiseren. In de praktijk werden de benodigde faciliteiten in de te ontginnen gebieden veelal door grotere bedrijven verschaft die daarin veel kapitaal investeerden en daarvoor ter plaatse veel inheemse arbeiders recruteerden. Zo liet de Steenkolen-Maatschappij 'Poeloe Laoet' kort na 1900 snel een volwaardige infrastructuur verrijzen op het gelijknamige eiland ten zuidoosten van Borneo: wegen, spoor, waterleiding, elektriciteit, kade, steigers, telefoonverbindingen werden aangelegd op kosten van de onderneming. Het bedrijf zag de aanleg van deze faciliteiten als een noodzakelijke investering waarop later afgeschreven werd; de winstverwachtingen waren dusdanig dat dit verantwoord werd geacht ${ }^{22}$. Soms kan het pionierswerk van de afzonderlijke onderneming rechtstreeks in verband worden gebracht met de vestiging van effectief koloniaal gezag ter plaatse. Dit was bijvoorbeeld het geval bij de goudmijn 'Pagoeat' in de residentie Menado in het noorden van Celebes (thans: Sulawesi) omstreeks de eeuwwisseling ${ }^{23}$.

Bij de Nederlandse investeringen in de kolonie kwamen zowel kapitaal als ondernemerschap en technologie van buiten. Voor de economische ontplooiing van de Buitengewesten gold dit eveneens voor de factor arbeid. In deze schaars bevolkte gebieden steunden de Westerse ondernemingen derhalve op geïmporteerde Chinese en Javaanse koelie-arbeid. Ook deze input in het produktieproces werd beschouwd als een noodzakelijke investering; de kosten van werving en vervoer van koelies werden dan ook gedurende de contractperiode afgeschreven. Tot 1931 was het systeem van koelie-arbeid wettelijke verankerd in de Koelie-ordonnantie die onevenredig veel macht gaf aan de werkgever. Over de schandalen rondom de toepassing van de poenale sanctie, het Rhemrevrapport en de instelling van de arbeidsinspectie is al veel geschreven $^{24}$. De kwestie van de arbeidsverhoudingen op de Westerse ondernemingen

21 Haasse, H eren van de thee, 109-132.

22 J. Baks, 'De Steenkolen-Maatschappij 'Poeloe Laoet' in Zuidoost-Borneo' in: Clemens, Lindblad, Het belang van de Buitengewesten, 123-146.

23 A. I. P. J. van Beurden, 'De Indische 'goldrush'. Goudmijnbouw en Nederlands beleid in NoordCelebes, 1880-1910' in: Van Goor, Imperialisme in de marge, 179-226.

24 J. Breman, Koelies, planters en koloniale politiek. Het arbeidsregime op de grootlandbouwondernemingen aan Sumatra's Oostkust in het begin van de twintigste eeuw (Dordrecht-Providence, 1987) 179219; A. Kamphues, 'Na Rhemrev. Arbeidsomstandigheden op de Westerse ondernemingen in de Buitengewesten van Nederlands-Indië, 1904-1938', Economisch-en sociaal-historisch jaarboek, LI (1988) 299-337. Over de recente discussie, vgl. Breman, Koelies (3e dr.; Leiden, 1992) 'Voorwoord'. 
buiten Java is een onderwerp apart waarop thans niet nader kan worden ingegaan. Hier wordt volstaan met de constatering dat dergelijke arbeidsverhoudingen waarschijnlijk in belangrijke mate hebben bijgedragen tot een vergroting van de kloof in mentaliteit tussen ondernemers in Nederland en in Nederlands-Indië.

Niet alleen de omstandigheden, waaronder de produktiefactoren gecombineerd moesten worden, waren in de kolonie anders. Ook de inrichting van de produktie zelf verschilde van wat men gewend was in het moederland. De relatief goedkopere arbeid noopte waar mogelijk tot een keuze voor een technologie die gekenmerkt werd door een lage kapitaal-intensiteit. Dit werd vooral gerealiseerd in de Westerse plantagebouw. De variatie per bedrijfstak springt bijzonder in het oog zodra we het patroon van kapitalisering bij de Westerse ondememingen in Nederlands-Indië rond 1930 nader beschouwen (grafiek V) ${ }^{25}$. Het accent lag sterk op niet-agrarische activiteiten, voornamelijk petroleum en overige mijnbouw, handel, nijverheid en overige diensten terwijl grote, toonaangevende exportsectoren zoals suiker en rubber een verrassend klein aandeel hadden in het totaal geïnvesteerde kapitaal.

\section{GRAFIEK V}

Kapitaal en winst naar bedrijfstak

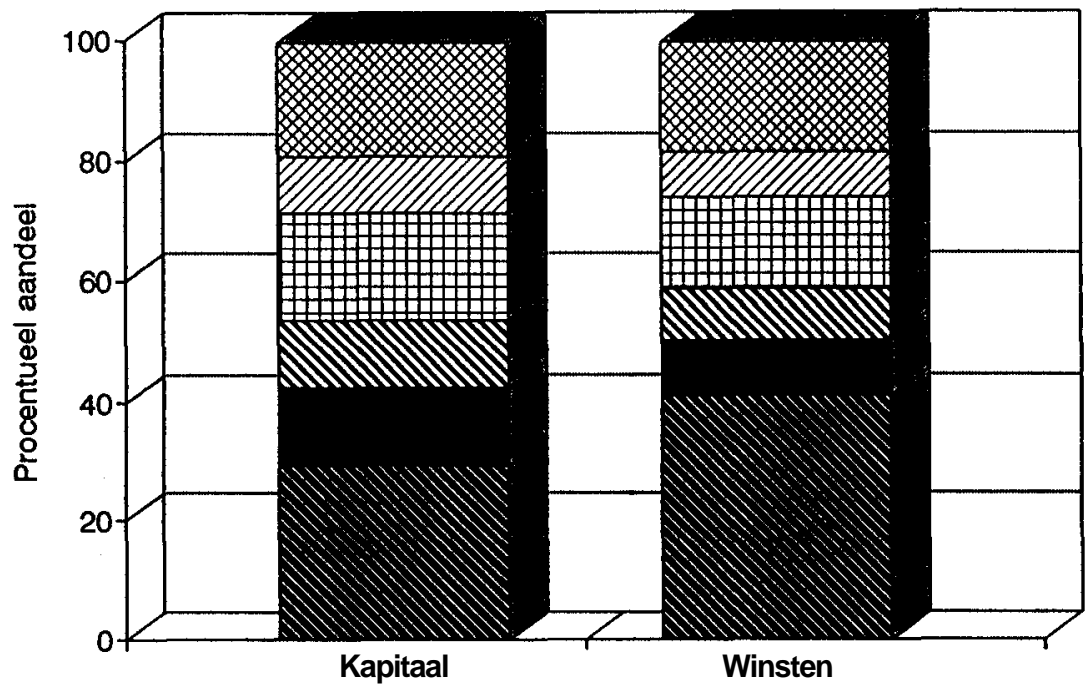

$$
\begin{array}{|ll}
\hline \text { Olie \& mijnbouw } & \text { Suiker } \\
\text { Over. landbouw }
\end{array}
$$

25 Bron voor Grafiek V: Handboek 1930. Het geaggregeerde kapitaal is ontleend aan het gestorte maatschappelijk kapitaal, bij elkaar $\{3,5$ miljard; enkele ondernemingen zijn weggelaten waarvoorhet niet mogelijk was het type activiteit vast te stellen (bij elkaar c. f0,2 miljard). Geen rekening kon worden gehoudenmet de aanwending van een deel van het maatschappelijkkapitaal buiten Nederlands-Indië. Het totaal is exclusief reserves. 
In de bedrijfstakken met een relatief kapitaal-intensieve produktie was een aanzienlijke variatie in rentabiliteit. De hoogste winstcijfers, althans voor zover deze zich aan de hand van uitgekeerde dividenden omstreeks 1930 laten bepalen, werden genoteerd in de olie, c. $15 \%$. Voor het overige schommelde het winst- of dividendpercentage rondom de $9-10 \%$, hetgeen nauwelijks afweek van het percentage dat ook in de landbouw werd gehaald ${ }^{26}$. Het behoeft geen lang betoog dat achter deze gemiddelde percentages, berekend over alle in de kolonie werkzame Westerse ondernemingen, veel verschillen per afzonderlijk bedrijf schuil gaan. Vele NV's keerden in het geheel geen dividend uit maar sluisden de winsten terug in het bedrijf. Andere gingen over tot buitensporige dividenduitkeringen in de orde van grootte van $200 \%$; dit was bijvoorbeeld het geval met de beide kleine theeplantages 'Santosa' en 'Kertasarie' in de Preanger in de jaren twintig. Er zijn talrijke voorbeelden van gelijktijdige royale uitkeringen en interne reserveringen.

De bedrijfsvoering in de afzonderlijke onderneming kreeg niet alleen gestalte door de externe omstandigheden en de keuze van de technologie. Ook de nationaliteit van het geïnvesteerde kapitaal speelde een rol. In aansluiting op de voorgaande analyse van het netwerk in de koloniale economie onderscheiden we een vijftal categorieën: 1 Nederlandse bedrijven (zetel in Nederland); 2 Nederlands-Indische bedrijven (zetel in de kolonie); 3 Chinese bedrijven; 4 Indonesische bedrijven; 5 Buitenlandse bedrijven (zetel in Nederland noch Nederlands-Indië), veelal Britse bedrijven.

\section{GRAFIEK VI}

Kapitaalen winst naar nationaliteit

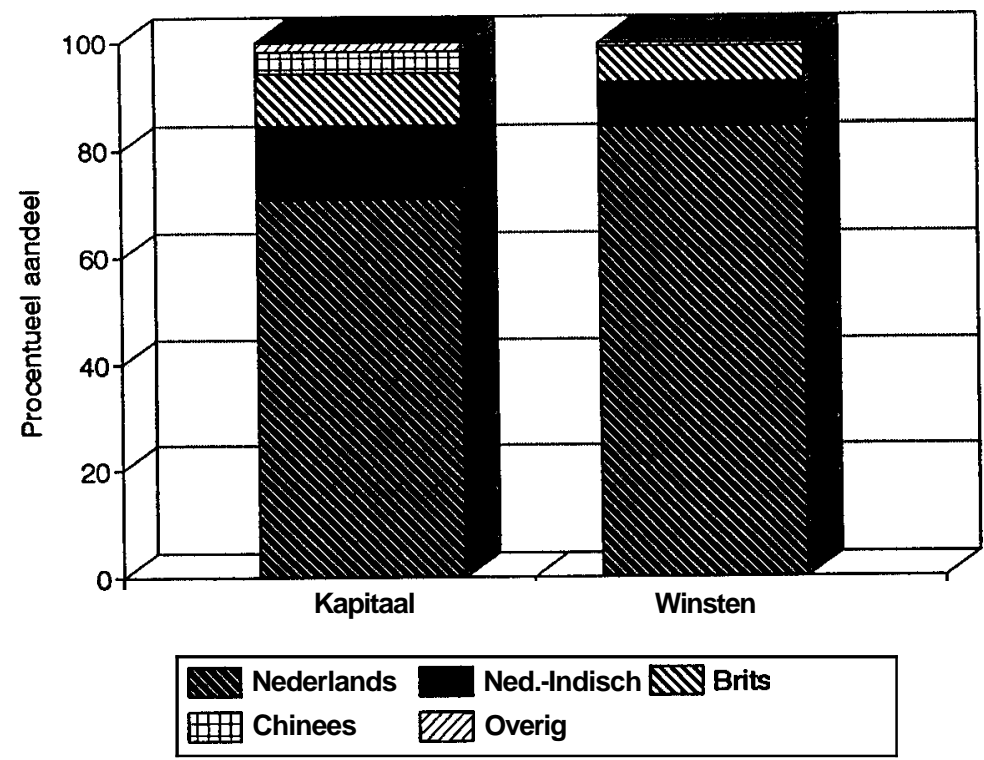

26 Deze percentages zijn niet zonder meer vergelijkbaar met schattingen die gebaseerd zijn op alleen de ondernemingen, die überhaupt dividend uitkeerden. Vgl. Lindblad, 'Het bedrijfsleven', 205. 
De aggregatie per nationaliteit laat duidelijk de suprematie van de Nederlandse bedrijven zien (grafiek VI) ${ }^{27}$. Hun aantal was niet groot maar het ging om relatief grote bedrijven. Exact het tegenovergestelde geldt voorde Nederlands-Indische en Chinese bedrijven: veel zeer kleine ondernemingen. Vergeleken met de Nederlands-Indische bedrijven lag de rentabiliteit van de Nederlandse bedrijven, zoals globaal aangeduid door de dividenduitkering, aanmerkelijk hoger, gemiddeld ongeveer $12 \%$ tegenover ca. 6\%. B ij de Chinese ondernemingen werd blijkbaar een belangrijk deel van de winst niet als dividend uitgekeerd; hiervan getuigt het te verwaarlozen kleine aandeel van deze ondernemingen in de geaggregeerde winstuitkering. Dergelijke markante verschillen in de rentabiliteit, of liever gezegd in het toegepaste uitkeringsbeleid, weerspiegelen een fundamenteel verschil in bedrijfsvoering.

De differentiatie naar nationaliteit stelt ons in staat een contrast aan te brengen in het patroon van bedrijfsvoering van met name Nederlandse en Nederlands-Indische ondernemingen. De Chinese en buitenlandse, en zeker de Indonesische bedrijven zijn allemaal speciale gevallen. De Nederlandse bedrijven streefden naar grootschaligheid en zij roomden de winsten behoorlijk af, terwijl de Nederlands-Indische ondernemingen eerder gericht waren op continuïteit en een vaste lokale verankering.

\section{Conclusie}

Ondernemen in Nederlands-Indië kan als manifestatie van ondernemersgedrag vanuit een drietal invalshoeken worden beschreven: de ontstaansgeschiedenis, het kader zoals dat in de loop der tijd is ontwikkeld en de bijzondere bedrijfsvoering in de kolonie. Deze concepten bieden aanknopingspunten voor een nadere studie per afzonderlijk bedrijf of bedrijfstak.

De opbouw van het Westerse bedrijfsleven in Nederlands-Indië was rechtstreeks gerelateerd aan de expansie van de uitvoer uit Nederlands-Indië en het ontstaan van een koloniale staat in de eerste decennia van de twintigste eeuw. Westerse ondernemingen vervulden een sleutelrol bij de dubbele integratie die toen in de kolonie plaats vond, naar buiten toe en binnen de archipel.

Aldus ontstond een volwaardig en fijnmazig netwerk van Westerse ondernemingen dat zich over de gehele archipel uitstrekte. Hierdoor werd ondernemen in de kolonie méér dan het opzetten en onderhouden van dépendances van kapitaalbelangen uit het moederland. Het netwerk onderstreept de (ogenschijnlijk) permanente aard van ondernemen in Nederlands-Indië.

De bedrijfsvoering in de kolonie ontleende haar bijzondere karakter zowel aan de grote afstand tot het moederland en de noodzaak om pionierswerk te verrichten als aan de specifieke combinatie van de vereiste produktiefactoren. We bespeuren een dichotomie tussen een tweetal patronen: grote Nederlandse bedrijven die vooral in winst geïnteresseerd waren en kleine Nederlands-Indische bedrijven voor wie de continuïteit belangrijker was. Het tijdsperspectief van de investeringen van de grote en het terugsluizen van winsten door de kleine bedrijven was moeilijk te verenigen met een snelle opmars naar de onafhankelijkheid van Indonesië.

27 Bron voor Grafiek VI: Handboek 1930. Het totaal geïnvesteerde kapitaal bedraagt f3,7 miljard. Voor nagenoeg elk afzonderlijk bedrijf was het mogelijk de nationaliteit te bepalen. 


\title{
Opkomst en ondergang van Anthony Fokker als internationaal vlieg- tuigbouwer, 1890-1939
}

\author{
MARC DIERIKX
}

My life has been paced by the airplane. Hurtling through space on what now seems a predestined course, I had no idea what that course was. Most of the time I merely hung on*.

\section{Inleiding}

De vliegtuigbouw behoort van oudsher tot de bij uitstek internationaal georiënteerde economische sectoren. Met uitzondering van de Verenigde Staten en de voormalige Sovjet Unie, is de binnenlandse vraag naar luchtvaartmaterieel in geen enkel land blijvend groot genoeg geweest om een vliegtuigindustrie in stand te houden. De luchtvaart zelfheeft zich altijd afgespeeld in het volle licht van de publieke belangstelling en het is daarom niet verwonderlijk dat de vliegtuigbouw, zoals trouwens ook het geval was met de nationale luchtvaartmaatschappijen, spoedig een exponent werd van het nationaal prestige. In Nederland deed dit zich nog in 1992 gelden rondom de overname van Fokker door Deutsche Aerospace/Daimler Benz.

$\mathrm{Al}$ spoedig na de eerste wereldoorlog bleken de exportmogelijkheden van de nieuw ontstane industrietak, de vliegtuigbouw, nauw samen te hangen met de in haar Produkten geboden technologie. In de periode tussen 1919 en 1940, waarin de luchtvaart een bijzonder snelle ontwikkeling doormaakte, was het daarom voor de Nederlandse vliegtuigbouwer Fokker, opererend vanaf een uiterst kleine thuismarkt, van belang een technologische voorsprong te behouden op de concurrentie om te kunnen penetreren op buitenlandse afzetmarkten. In deze bijdrage zal worden nagegaan in hoeverre Fokker dit belang onderkende en wat de gevolgen daarvan waren voor zijn bedrijf.

Al wordt de Fokkerfabriek tot de grootste industriële concerns van Nederland gerekend ${ }^{1}$, toch is haar geschiedschrijving, zoals trouwens die van de gehele luchtvaartsector, tot dusverre beperkt. Weliswaar verschenen over Fokker meer dan een dozijn boeken, maar aan geen daarvan kunnen akademische kwalificaties worden toegedicht; het gaat hier om journalistiek werk voor een breed publiek, dan wel om

*Anthony Fokker, in: A. H. G. Fokker, B. Gould, Flying Dutchman. The life of Anthony Fokker (New York, 1931) 10 .

1 J. L. van Zanden, R. T. Griffith, Economische geschiedenis van Nederland in de 20 e eeuw (Utrecht, 1989) 271. 